\title{
Perencanaan Dan Analisis Ekonomi Pembangkit Listrik Tenaga Surya (PLTS) Terpusat Untuk Desa Mandiri
}

\author{
Bambang Winardi ${ }^{1}$, Agung Nugroho $^{2}$, Erlin Dolphina ${ }^{3}$ \\ ${ }^{12}$ Departemen Teknik Elektro, Universitas Diponegoro Semarang \\ ${ }^{3}$ Teknik Informatika, Universitas Dian Nuswantoro, Semarang \\ 1Email : bbwinar@gmail.com, ${ }^{2}$ agung.nugroho@gmail.com, ${ }^{3}$ erlindolphina@gmail.com
}

\begin{abstract}
Solar cell or photovoltaic became one of the renewable energy which has great potential to be applied in Indonesia. Kaliwungu used communal photovoltaic system source of electrical energy., used load data in Kaliwungu to determined the capacity solar systems (photovoltaic array, battery, charge controller, and inverter), the potential reduction of carbon dioxide emissions, cost, and economic analysis. Economic analysis is used to evaluated the continuity of the photovoltaic system. Analysis used several methods NPW (Net Present Worth), ACF (Annual Cash Flow analysis), B-CR (Benefit-Cost Ratio analysis), FW (Future Worth analysis), and PP (Payback Period). Calculated used software MATLAB 2008a. The result shows to supply the daily load at $8,922 \mathrm{kWh}$ can be supplied from the photovoltaic system with a capacity up to 2,85 $\mathrm{kWp}$, battery at 464,678 Ah, charge controller up to $60 \mathrm{~A}$, and the inverters at $3500 \mathrm{~W}$. For the potential carbon dioxide emissions reduction up to 3,640 ton $\mathrm{CO} 2$. The value $\mathrm{R} p$-266.351.000,00 for NPW, Rp -23.894.600,00 for ACF, Rp 714.063.000,00 for $\mathrm{FW}$, $B-C R$ was 0.3850 , and 29 years for $P P$.
\end{abstract}

Keywords : photovoltaic system, benefit-cost ratio analysis, future worth, payback period.

\section{PENDAHULUAN}

Sebagian besar manusia masih mengandalkan energi fosil untuk kebutuhan energy listrik, sehingga cadangan energi fosil di Indonesia semakin menipis.[1] Dalam buku Outlook Energi Indonesia tahun 2013, kenaikkan pemakaian energi rata - rata pemakain energi sebesar 4,7\% per tahun dari tahun 2011 - 2030. [2]. Dari permasalahan tersebut diperlukan cara-cara pengembangan teknologi energy baru dan terbarukan untuk memenuhi kebutuhan energy listrik dengan cara memanfaatkan energy baru dan terbarukan yang ramah lingkungan. Pembangkit Listrik Tenaga Surya (PLTS) merupakan pembangkit energy listrik yang memanfaatkan sinar matahari yang potensinya sangat melimpah di Indonesia sepanjang tahun dengan potensi radiasi sinar matahari dengan ratarata $4,8 \mathrm{kWh} / \mathrm{m} 2 /$ hari, [2]. Sinar matahari merupakan jenis sumber energi primer yang umumnya digunakan untuk menghasilkan energi listrik. 
Faktor- faktor yang dapat mempengaruhi besarnya efisiensi daya yang mempengaruhi besarnya keluaran sel surya antara lain radiasi matahari, temperature pada sel surya, orientasi dari panel surya (array), sudut kemiringan dari panel surya (array), dan besarnya bayangan.[3] Besarnya daya yang dihasilkan oleh sel surya tergantung besarnya radiasi matahari yang mengenai modul, demikian juga dengan temperatur yang terdapat pada sel surya. Untuk menaikkan daya output yang dihasilkan, diusahakan sel surya selalu memperoleh radiasi matahari yang maksimal juga diperlukan temperatur yang rendah supaya daya output meningkat,[3]

Pembangunan PLTS memerlukan biaya pemasangan yang sangat mahal untuk saat ini. Oleh karena itu, diperlukan perhitungan ekonomi yang meliputi besarnya investasi awal yang harus disediakan. Selain itu diperlukan kajian ekonomi dan studi kelayakkan proyek untuk menghitung berapa lama pengembalian investasi awal dan layak atau tidak pembangunan pembangkit listrik tenaga surya tersebut.[4,5] Penelitian didahului dengan perhitungan kapasitas dan jumlah peralatan yang dipergunakan dalam pembangunan sistem PLTS tersebut antara lain jumlah panel surya, jumlah dan kapasitas baterai, charge controller, dan jenis inverter.[3,6]

Pada penelitian ini akan menganalisis pembangunan PLTS terpusat yang lokasinya di Desa Kaliwungu yang terletak di Kabupaten Banjarnegara jawa tengah. Penelitian dengan memperhitunan aspek bidang teknik untuk menghitung besar kapasitas dari peralatan sistem PLTS (photovoltaic) yang digunakan.

Tujuan yang hendak dicapai dalam Penelitian ini adalah :

1. Menentukan besar kapasitas peralatan sistem photovoltaic pada PLTS di Desa Kaliwungu Kecamatan Mandiraja Kabupaten Banjarnegara.

2. Menghitung dan menganalisis perkiraan biaya menggunakan metode ekonomi teknik untuk mengetahui kelayakan investasi proyek PLTS.

\section{METODE}

\subsection{Pembuatan Program Simulasi}

Perancangan pembuatan program simulasi untuk analisis kapasitas PLTS dan analisis ekonomi pembangunan pembangkit listrik tenaga surya (PLTS), terlihat pada diagram alir dibawah ini : 


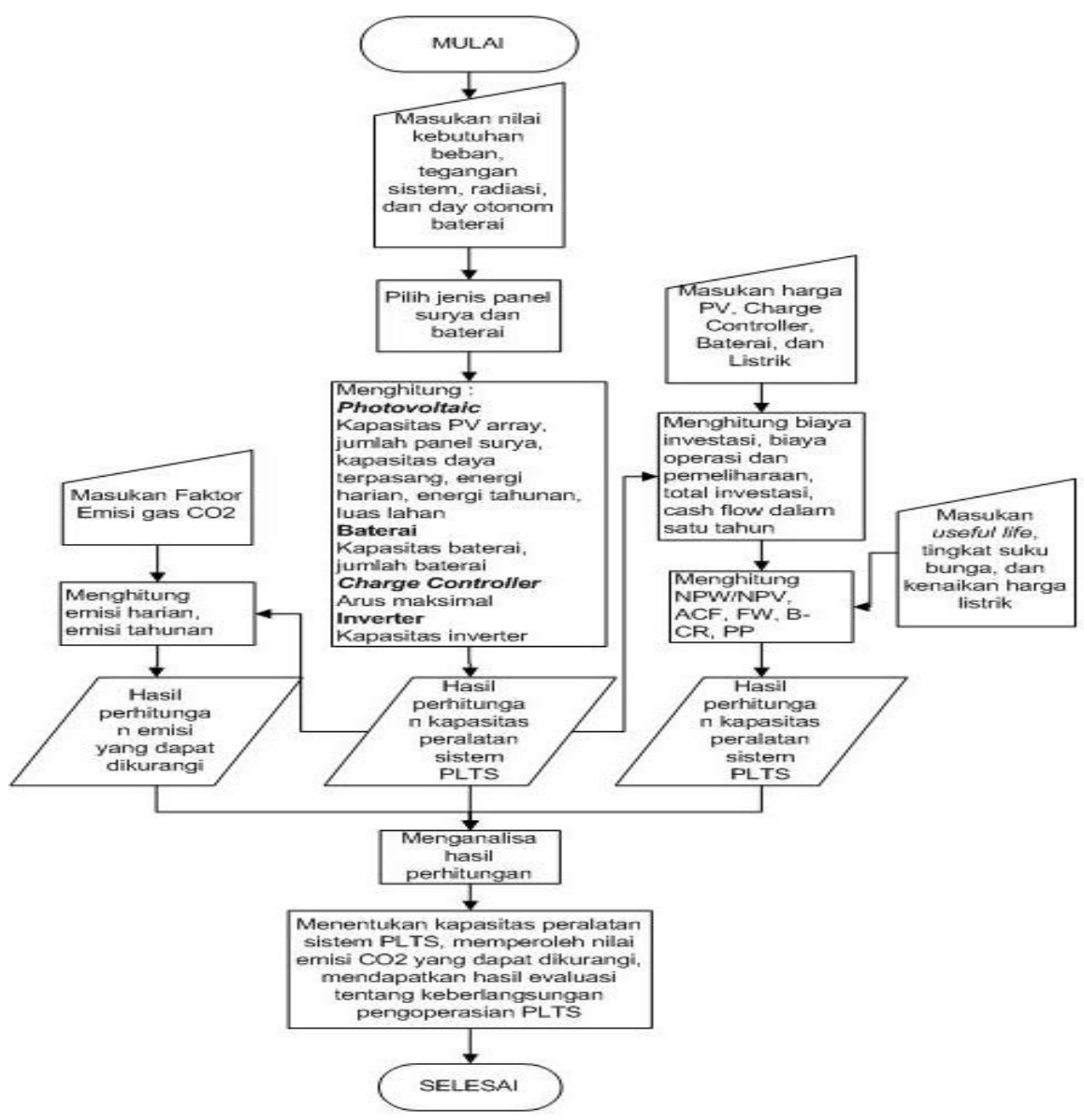

Gambar 1. Diagram alir Pembuatan program Simulasi

Program simulasi ini terdiri dari 4 macam tampilan, yaitu halaman awal judul, Perhitungan besar kapasitas PLTS, dan perhitungan investasi dan analisis ekonomi teknik. Sebagai data input program pada tampilan perhitungan kapasitas dari PLTS dipergunakan data masukan berupa total beban yang akan disuplai oleh PLTS.

Data beban terlihat pada Tabel 1, tegangan yang akan digunakan, baterai dan radiasi matahari rata - rata terukur di lokasi penelitian sesuai dengan data yang diperoleh dari NASA seperti terlihat pada Tabel 1. 
(Civil Engineeering, Elektrical Engineeering and Industrial Engineeering)

Vol. 16, No. 2 Oktober 2019 , p-ISSN:1907-5243, e-ISSN: 2655-8416

Tabel 1. Total beban Desa Kaliwungu

\begin{tabular}{|c|c|c|c|c|c|c|}
\hline Beban & $\begin{array}{l}\text { Daya } \\
\text { (Watt) }\end{array}$ & $\begin{array}{c}\text { Jumlah } \\
\text { titik }\end{array}$ & $\begin{array}{c}\text { Waktu } \\
\text { pemakaian }\end{array}$ & $\begin{array}{c}\text { Lama } \\
\text { pemakaian } \\
\text { (jam) }\end{array}$ & $\begin{array}{l}\text { Jumlah } \\
\text { rumah }\end{array}$ & $\begin{array}{l}\text { Total } \\
(\mathrm{kWh})\end{array}$ \\
\hline Lampu (Rumah) & 8 & 3 & $\begin{array}{c}18.00- \\
06.00\end{array}$ & 12 & 30 & 8,64 \\
\hline Lampu (Mushola) & 8 & 2 & $\begin{array}{l}18.00- \\
21.00\end{array}$ & 3 & 1 & 0,048 \\
\hline Lampu (Umum) & 8 & 1 & $\begin{array}{l}18.00- \\
21.00\end{array}$ & 3 & 1 & 0,024 \\
\hline Televisi (Umum) & 70 & 1 & $\begin{array}{c}18.00- \\
21.00\end{array}$ & 3 & 1 & 0,21 \\
\hline Total Energi & & & & & & 8,922 \\
\hline
\end{tabular}

Tabel 2. Data radiasi matahari terukur

\begin{tabular}{|l|c|}
\hline \multicolumn{1}{|c|}{ Bulan } & $\begin{array}{c}\text { Radiasi matahari } \\
\left(\mathrm{kWh} / \mathrm{m}^{2} / \text { hari }\right)\end{array}$ \\
\hline Januari & 4,33 \\
\hline Febuari & 4,52 \\
\hline Maret & 4,58 \\
\hline April & 4,65 \\
\hline Mei & 4,61 \\
\hline Juni & 4,43 \\
\hline Juli & 4,65 \\
\hline Agustus & 4,94 \\
\hline September & 5,19 \\
\hline Oktober & 4.96 \\
\hline November & 4.46 \\
\hline Desember & 4.60 \\
\hline Rata-rata & 4,66 \\
\hline
\end{tabular}

Sumber : www. eosweb.larc.nasa.gov

Untuk tampilan biaya investasi awal dan perhitungan ekonomi dipergunakan data input berupa harga panel surya, harga baterei, charge controller, dan juga harga inverter serta harga penjualan energi listrik PLTS sebesar Rp 3.000,-/kWh, besar tingkat suku bunga sebesar 7,5\%, dan project life yang direncanakan, yaitu 25 tahun. 


\subsection{Metode Pengolahan Data}

Setelah melakukan pengumpulan data maka dilakukan pengolahan data dengan persamaan-persamaan berikut [7]:

1. Biaya $(\operatorname{Cos} t)$

Dalam analisis ekonomi teknik, satuan biaya dari pembangunan proyek atau proses suatu produksi digolongkan beberapa kelompok, yaitu:.

1) Biaya investasi

2) Biaya operasional

3) Biaya pergantian alat dan biaya perawatan.

Besar biaya operasional dan perawatan sebesar 5\% dari biaya investasi.[3].

Sehingga didapatkan total biaya menggunakan Persamaan (1) sebagai berikut :

Total Biaya $=$ Biaya investasi + Biaya operasional dan perawatan

\section{Net Present Value (NPV) / Net Present Worth (NPW)}

Dengan metode ini kelayakan suatu investasi awal atau pemilihan berbagai alternatif, semua proyeksi cashflow pada masa depan diharuskan dinyatakan pada nilai sekarang yang ekivalen dengan besar tingkat suku bunga untuk dijadikan perbandingan. Analisis nilai sekarang (Present Worth Analysis) paling sering digunakan untuk menentukan nilai tunai penerimaan dan pencairan uang di masa depan. Jika pendapatan masa depan dan biaya diketahui, menggunakan tingkat bunga yang sesuai, nilai sekarang dapat dihitung. Di dalam kasus, konsekuensi dari setiap alternatif harus dipertimbangkan untuk periode waktu.

Persamaan (2) sampai dengan Persamaan (4) di bawah ini merupakan persamaan untuk mencari nilai bersih sekarang:

Net PV $=\Sigma$ PVbenefit $-\Sigma$ PVcost

Dimana :

$\mathrm{PW}$ of Benefit $=\mathrm{A}(\mathrm{P} / \mathrm{A}, \mathrm{i}, \mathrm{n})$

$(\mathrm{P} / \mathrm{A}, \mathrm{i}, \mathrm{n})=\left(\llbracket(1+\mathrm{i}) \rrbracket^{\wedge} \mathrm{n}-1\right) / \llbracket \mathrm{i}(1+\mathrm{i}) \rrbracket^{\wedge} \mathrm{n}$

Dimana :

$$
\begin{array}{ll}
\text { PW of Cost } & =\text { biaya yang dikeluarkan (biaya investasi) } \\
P W \text { of Benefit } & =\text { kas masuk } \\
\mathrm{i} & =\text { tingkat suku bunga } \\
\mathrm{n} & =\text { periode }
\end{array}
$$


Kriteria pengambilan keputusan yang diambil akan tergantung kepada situasi pemilihan alternatif investasi, yaitu sebagai berikut :

Net PV $<0$ (negatif) $=$ Tolak Investasi

Net PV $>0$ (positif) $=$ Terima Investasi

\section{Annual Cash Flow Analysis (ACF)}

Untuk menghitung jumlah setara saat ini, bisa dengan membandingkan alternatif berdasarkan arus kas tahunan setara (equivalent annual cash flows). Dalam situasi tertentu, dimungkinkan untuk menghitung Equivalent Uniform Annual cost (EUAC), Equivalent Uniform Annual Benefit (EUAB), atau selisih antara keduanya (EUAB-EUAC ).

\section{Future Worth Analysis (FW)}

Future worth analysis (analisa nilai yang akan datang) seperti analisis nilai sekarang hanya berbeda waktu sekarang dan yang akan datang .

Sebagai mana dapat terlihat pada Persamaan (5) dan Persamaan (6) sebagai berikut :

Dimana :

$$
\begin{aligned}
& \mathrm{FW}=\mathrm{A}(\mathrm{F} / \mathrm{A}, \mathrm{i}, \mathrm{n}) \\
& (\mathrm{F} / \mathrm{A}, \mathrm{i}, \mathrm{n})=\left([(1+\mathrm{i})]^{\wedge} \mathrm{n}-1\right) / \mathrm{i}
\end{aligned}
$$

$$
\begin{aligned}
\mathrm{A} & =\text { pendapatan yang diterima } \\
\mathrm{i} & =\text { tingkat suku bunga } \\
\mathrm{n} & =\text { periode }
\end{aligned}
$$

Dengan nilai A merupakan arus kas yang diperoleh dan (F/A,i,n) merupakan compound factor untuk analisis nilai yang akan datang pada periode ke-n.

\section{Benefit - Cost Ratio Analysis (B-CR)}

Analisa manfaat biaya (benefit cost analysis) adalah metode praktis yang dipergunakan untuk menilai kemanfaatan suatu proyek, dimana diperlukan analisa yang panjang dan luas.

Misal $\mathrm{B}=$ benefit dan $\mathrm{C}=$ cost, maka perbandingan benefit dan cost dihitung dengan Persamaan (7).

$$
\mathrm{B} / \mathrm{C}=\mathrm{PWB} / \mathrm{PWC}=\mathrm{EUAB} / \mathrm{EUAC}
$$

Untuk suku bunga i, bila $\mathrm{B} / \mathrm{C}>1$ maka proyek dinyatakan acceptable dan bila $\mathrm{B} / \mathrm{C}<1$ maka suatu proyek dinyatakan tidak dapat diterima. 


\section{Payback Period (PP)}

Payback period merupakan suatu metode untuk mengetahui berapa lama investasi modal akan kembali atau berapa lama waktu yang diperlukan kembali pengeluaran investasi

Persamaan payback period jika aliran kas dari rencana investasi suatu proyek sama jumlahnya pada setiap tahun terlihat pada Persamaan (8) :

Payback Period $=\frac{\text { Initial Investement }}{\text { Cash Flow }} \times 1$ tahun

\subsection{Pengoperasian Program Simulasi}

Program analisis kapasitas dan biaya pembangkit listrik tenaga surya (PLTS) komunal Desa Kaliwungu Kabupaten Banjarnegara disimulasikan dengan memanfaatkan GUI (Graphic User Interface) pada Software MATLAB 2008.a. Penggunaan GUI bertujuan memudahkan dalam mengoperasian program dan melihat hasil perhitungan besar kapasitas peralatan yang ada di sistem PLTS, perhitungan biaya serta perhitungan ekonomi teknik untuk mengetahui keberlangsungan dari pengoperasian PLTS tersebut.

Tampilan pada halaman perhitungan dari kapaitas sistem PLTS, serta perhitungan biaya dan analisis ekonomi teknik dari program terlihat pada Gambar 2, 3, berikut.

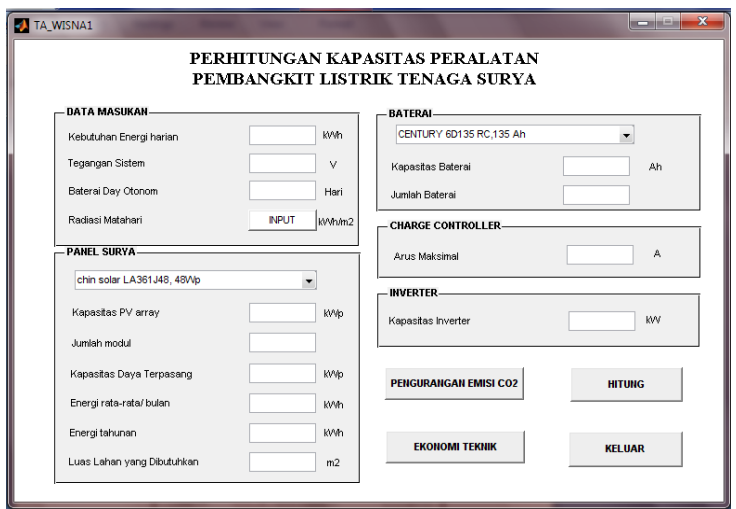

Gambar 2. Tampilan perhitungan kapasitas PLTS 


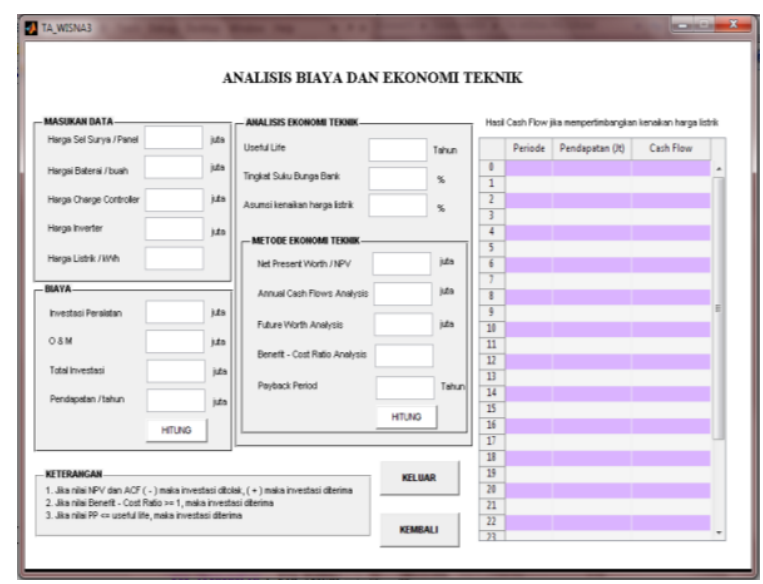

Gambar 3. Tampilan perhitungan biaya dan analisis ekonomi teknik

\section{PEMBAHASAN}

\subsection{Perhitungan Kapasitas Peralatan Sistem PLTS}

Total beban yang akan disuplai oleh pembangkit Listrik Tenaga Surya di Desa Kaliwungu Kabupaten Banjarnegara sebesar 8.923 Wh ( 8,923 kWh ). Hasil dari perhitungan menunjukkan besar kapasitas daya yang terpasang pada PLTS sebesar 2,850 KWp. Sedangkan potensi energi bulanan yang dihasilkan photovoltaic array rata-rata sebesar $415,590 \mathrm{kWh} / \mathrm{m}^{2} /$ hari dan jumlah potensi energi tahunan sebesar 4987,103 kWh/m². Sedangan luas lahan yang digunakan untuk pembangunan Pembangkit Listrik tenaga Surya (PLTS) seluas 23,910 $\mathrm{m}^{2}$. Sistem PLTS Desa Kaliwungu menggunakan jenis modul surya model BP3150N dengan besar kapasitas daya maksimal $150 \mathrm{Wp}$ tiap modul, jumlah modul surya yang digunakan sejumlah 36 modul. Sehingga besar kapasitas photovoltaic array yang terpasang sebesar $5 \mathrm{kWp}$ dengan menggunakan luas lahan 45,304 $\mathrm{m}^{2}$.

Perhitungan hasil program simulasi didapatkan arus I yang dihasilkan sebesar 59,376 Ampere. Sehingga pemilihan untuk kapasitas dari charge controller yang dapat dipakai harus mempunyai spesifikasi lebih besar atau sebesar 59,375 A. Sedangkan jika melihat kapasitas yang ada dipasaran, maka pemakaian besar arus maksimal 59,375 A dari kapasitas charge controller yang tersedia adalah kapasitas sebesar $60 \mathrm{~A}$.

Inverter yang dipergunakan juga harus disesuaikan dengan tegangan sistem PLTS dan berdasarkan hasil perhitungan arus maksimum charge controller, maka tegangan masukan inverter yang harus digunakan sebesar 48 Volt DC dan tegangan output inverter sebesar 220 Volt AC sesuai dengan tegangan listrik PLN. Dengan menggunakan tegangan sistem $48 \mathrm{~V}$ maka besar kapasitas dari inverter

8 | Perencanaan Dan Analisis Ekonomi Pembangkit Listrik Tenaga Surya (PLTS)

Terpusat Untuk Desa Mandiri 
yang harus digunakan adalah $2,850 \mathrm{~kW}(2850 \mathrm{~W})$. Jadi dapat menggunakan jenis inverter dengan besar kapasitas $3500 \mathrm{~W}, 48 \mathrm{~V}$ DC.

\subsection{Perhitungan Investasi dan Analisa Ekonomi Teknik}

Pada penelitian ini menggunakan perhitungan biaya investasi modal, besar biaya operasional dan biaya pemeliharaan dan pendapatan yang akan diterima tiap tahunnya. Hasil dari perhitungan biaya investasi adalah sebagai berikut:

Dengan memasukan sejumlah biaya pembelian peralatan yang digunakan, akan diketahui besar biaya investasi awal yang akan dikeluarkan nantinya sebesar Rp 412.500.000,-, besar biaya operasional dan biaya pemeliharaan sejumlah Rp 20.625.000,-, sehingga total biaya keseluruhan system yang harus disediakan adalah sejumlah Rp 433.125.000,-, dengan pendapatan per tahun sebesar Rp 14.961.400,-.

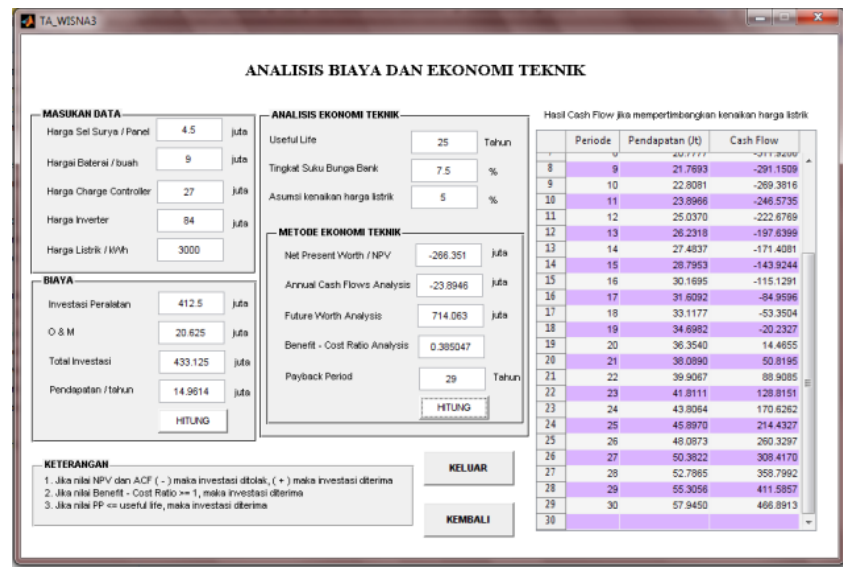

Gambar 4. Hasil simulasi : perhitungan analisis ekonomi teknik

Hasil perhitungan simulasi dengan cara metode ekonomi teknik mendapatkan nilai NPW sejumlah Rp -266.351.000,-, ACF sebesar Rp 23.894.600,-, FW sebesar Rp 714.063.000,-, B-CR sebesar 0,385 dan Payback Period selama 29 thn jika pemasukkan yang dihasilkan setiap tahunnya konstan.

Gambar berikut ini adalah grafik aliran kas. 


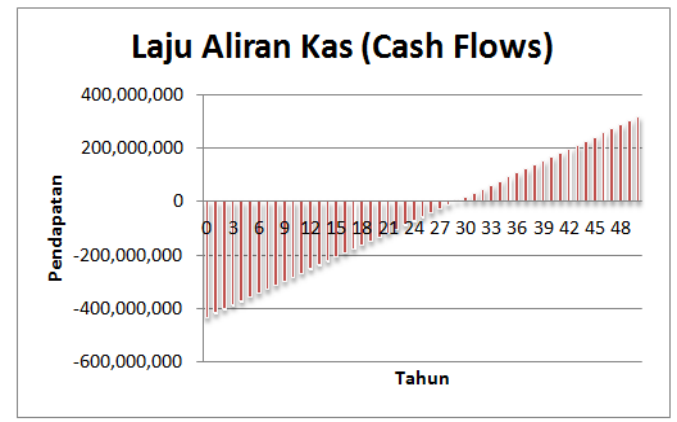

Gambar 5. Laju aliran kas pendapatan per tahun.

Apabila bila terjadi kenaikan tarif listrik per tahunnya maka lama kembalinya investasi terjadi pada tahun ke 22 .

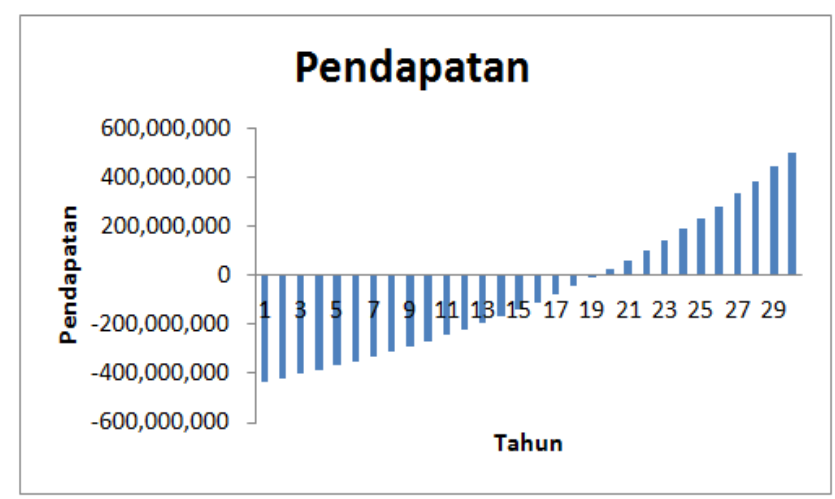

Gambar 6. Laju aliran kas masuk jika mengalami kenaikan tarif listrik sebesar 5\% tiap tahun.

\section{KESIMPULAN}

Kapasitas peralatan pada sistem photovoltaic pada sistem Pembangkit Listrik Tenaga Surya (PLTS) di Desa Banjarnegara Kabupaten Banjarnegara terhitung dengan memakai perhitungan dengan MATLAB didapatkan kapasitas photovoltaic array adalah sebesar 2,850 kWp. Sedangan jumlah modul yang digunakan sejumlah 19 unit. Kapasitas baterai sebesar 464,687 Ah, sedangkan jumlah baterai hasil perhitungan dihasilkan sebanyak 24 unit. Untuk arus I maksimal yang diijinkan mengalir pada peralatan charge controller sebesar 59,376 A, menggunakan charge controller dengan besar kapasitas arus sebesar $60 \mathrm{~A}$. Sedangkan daya maksimal inverter $2850 \mathrm{~W}$, sehingga inverter digunakan berkapasitas $3500 \mathrm{~W} / 48 \mathrm{~V}$ DC. 
Potensi energi yang dihasilkan oleh PLTS Desa Kaliwungu dengan kapasitas 2,85 $\mathrm{kWp}$ adalah 4987,13 kWh per tahun. Biaya total investasi yang dikeluarkan untuk investasi peralatan sistem photovoltaic sebesar $\mathrm{Rp}$ 433.125.000,- besar rincian besar biaya investasi modal peralatan $\mathrm{Rp} 412.500 .000$,- dan biaya operasional dan biaya pemeliharaan sebesar Rp 20.625.000,-. Dengan besar pendapatan Rp 14.961.400,tiap tahun. Untuk nilai net present value / worth sebesar Rp -266.351.000,-, annual cash flows analysis sebesar Rp -23.894.600,-. Untuk benefit-cost ratio adalah 0,3850, future worth sejumlah Rp 714.063.000,-. Dengan waktu pengembalian investasi di akhir project life selama 29 tahun. Jika kenaikan tarif listrik sebesar 5\%/tahun, waktu pengembalian investasi modal akan terjadi tahun ke 20 .

\section{DAFTAR PUSTAKA}

[1] Gati, Thomas, Ferdinan, Yohanes, 2006. Desain Pbotovoltaic di Kontrakan Ferdinan dengan Menggunakan RETScreen ${ }^{\circledR}$ Energy Model-Photovoltaic Project.Universitas Gajah Mada. Jogjakarta.

[2] Outlook Energi Indonesia 2013. Badan Pengkajian dan Penerapan Teknologi. Indonesia.

[3] Syahputra, Rhezi. 2013. Perencanaan Pembangkit Listrik Tenaga Surya Sistem Stand Alone Kapasitas 900 Watt Peak untuk. Rumah Tinggal di Purwokerto. Universitas Jendral Soedirman. Purwokerto.

[4] Newnan, Donald G. 1990. Engineering Economic Analysis Third Edition. Binapura Aksara.1990.

[5] Shahinzadeh, Hossein 2013. Tecbnical and Economic Study for Use The Photovoltaic System for Electricity Supply in Isfahan Museum Park. International Journal of Scientific and Technology Research Volume 2. ISSUE 1. .

[6] Astrawan Putra, Putu Yudi. 2007. Perancangan dan Pembuatan Simulasi Pembangkit Listrik Tenaga Surya (PLTS). Universitas Pendidikan Ganesha. Singaraja.

[7] Newnan, Donald G.1990. Engineering Economic Analysis,Edisi 3, Binarupa

Aksara.

[8] Duffie, John A. and William A. Beckman, 2006. Solar Engineering of Thermal Processes, $3^{\text {th }}$,Jon Wiley \& Sons, Inc, New Jersey.

[9] Larasati, Pangestunigtyas Diah, 2013. Analisis Pengaruh Sudut Kemiringan Panel Surya Terbadap Radiasi Matahari yang Diterima oleh Panel Surya Tipe Array Tetap. Universitas Diponegoro. Semarang.

[10] Maters, Gilbert M. 2004. Renewable and Efficient Electric Power System. A John Wiley \& Sons. Inc. 